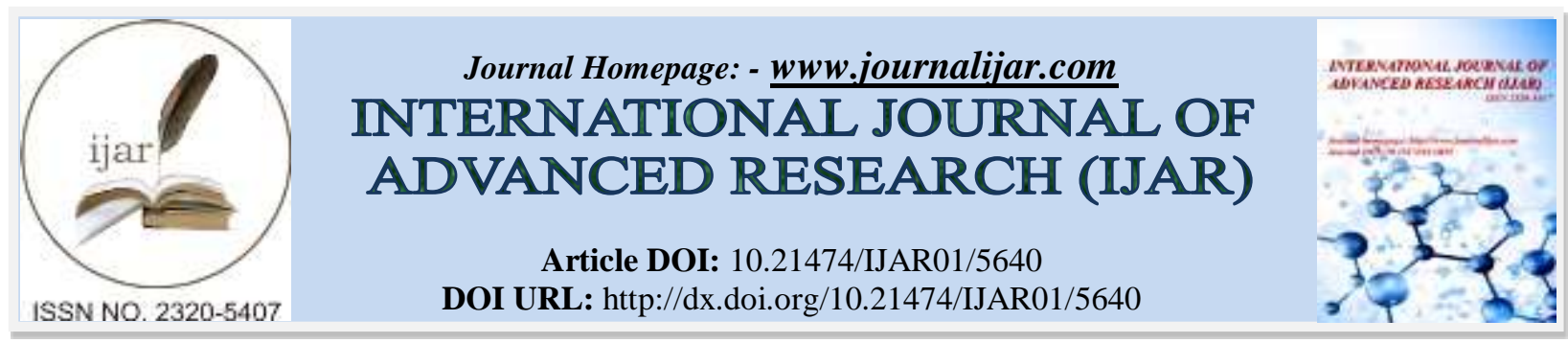

RESEARCH ARTICLE

\title{
VALORIZATION OF CISSUS POPULNEA (GUILL \& PERR) AND SYNEDRELLA NODIFLORA (L.) GAERTN IN RABBIT BREEDING IN BENIN: IMPACT ON REPRODUCTIVE PERFORMANCES, BLOOD CELLS COUNT AND HEMATOCRIT.
}

\author{
Aholou R.B. ${ }^{1}{ }^{*}$ Tougan Polycarpe Ulbad ${ }^{1,2}$, Daouda I-H. ${ }^{2}$, Kpodekon T.M. ${ }^{3}$, Zannou M.S. ${ }^{4}$, Hennou G.E.H. ${ }^{1}$ \\ Goudjihounde M. ${ }^{1}$, Hanzen $\mathrm{Ch}^{5}{ }^{5}$ and Koutinhouin G. Benoît ${ }^{1}$. \\ 1. Research Unit of Animal Husbandry and Meat Products Quality Control of Animal Production and Health \\ Department, Polytechnic School of Abomey-Calavi, 01 BP 2009, Cotonou, Republic of Benin, Benin. \\ 2. Faculty of Agronomy, University of Parakou, Republic of Benin. \\ 3. Department of Animal Production and Health, Polytechnic High School of Abomey-Calavi, 01 BP 2009, \\ Cotonou, Republic of Benin, Benin. \\ 4. Regional Excellence Centre of Avian Sciences of the University of Lome, BP 1515, Lome, Republic of Togo. \\ 5. Service de Thériogénologie, Département clinique des animaux de production, Faculté de Médecine Vétérinaire \\ Université de Liège.
}

\section{Manuscript Info}

Manuscript History

Received: 16 August 2017

Final Accepted: 18 September 2017

Published: October 2017

Key words:-

Benin, haemogram, hormonal plants, rabbit, reproductive traits, Synedrella nodiflora.

\section{Abstract}

The current study aims to compare the effect of Cissus populnea (Guill \& Perr) and Synedrella nodiflora (L.) Gaertn on reproductive traits and hemogram in rabbit do. Then, 60 nulliparous rabbits do and 12 males were divided into 3 lots. In lot 1, the animals hadn't received any plant treatment. In lot 2 , rabbits do and males were subjected to pellet feeds containing $10 \%$ of Cissus populnea dried leaves flour. In lot 3, rabbits do and males were subjected to pellet feeds containing $10 \%$ of Synedrella nodiflora dried leaves flour. It appears that the highest litter size was recorded in lot 2 and lot $3(\mathrm{P}<0.001)$ while the highest live weights at birth, at 35 days and at 56 days old were found in lot 1 . The greatest average daily gain $(32.2 \mathrm{~g} /$ day $)$ was recorded in animals of lot $3(\mathrm{P}<0.01)$. The fertility rate of lot 2 and lot 3 was respectively $90 \%$ and $92.5 \%$, to $85 \%$ in the control lot $(\mathrm{P}<0.001)$. Concentration in white blood cells red blood cells, and hemoglobin, and the hematocrit were respectively $6.23 \times 10^{3} / \mu \mathrm{L}, 5.63 \times 10^{6} / \mu \mathrm{L}, 11.3 \mathrm{~g} / \mathrm{Dl}$ and $37.50 \%$ in rabbits in the control group, to $6.05 \times 10^{3} / \mu \mathrm{L}, 5.63 \times 10^{6} / \mu \mathrm{L}, 11,55 \mathrm{~g} / \mathrm{Dl}$ and $38.85 \%$ in rabbits of lot 2 and $6.96 \times 10^{3} / \mu \mathrm{L}, 5.79 \times 10^{6} / \mu \mathrm{L}, 11.2 \mathrm{~g} /$ $\mathrm{Dl}$ and $37.3 \%$ in rabbits of the lot 3. Overall, the main effect of leaves of Cissus populnea and Synedrella nodiflora is to increase litter size and to reduce kidding interval in rabbit does.

Copy Right, IJAR, 2017,. All rights reserved.

\section{Introduction:-}

Rabbit breeding is a source of important cash income for households in Sub-Saharan Africa in general and particulary in Benin. Rabbit meat is very appreciated by consumers for its good nutritional and dietary values (Zotte Dalle, 2005). This lean meat type has a high rate of unsaturated fatty acids, low in cholesterol, proteins of high 
biological value and rich in macro-elements including potassium, phosphorus and magnesium (INRA, 2004; Djago et al., 2007). The manure is also used for soil fertility management.

In Benin, rabbit production is an activity of great economic interest which is currently emerging and practiced in all districts. The statistics reported by the Association of Rabbit Breeders (ARB) of Benin indicate that the number of rabbits does increased from 2251 in 1998 to 17200 in 2007 with a numerical productivity at weaning varying from 20 to 25 rabbits per female per year (Akpo et al., 2008). The improvement of this productivity depends on the control of feeding, health monitoring, rabbit breeding management and reducing mortality of young rabbits (Farougou et al., 2005; Kpodékon et al., 2006; Akpo et al., 2008 ; Koutinhouin et al., 2009a, Kpodékon et al., 2010). In tropical conditions, rabbit produces an average of 6.4 rabbits per litter (Djago and Kpodékon, 2000; Lebas et al., 2004), and the litter size at weaning is on average 4.8 rabbits (Kpodékon et al., 2004, Koutinhouin et al., 2009b). The fertility rate is $81 \%$ in nulliparous does, $61 \%$ in primiparous and $50 \%$ in multiparous (Koutinhouin et $a l ., 2009 \mathrm{a}$ ). The average live weight of weaned rabbit varies between $483 \mathrm{~g}$ and $650 \mathrm{~g}$ at 35 days of age (Akpo, 2004; Akpo et al., 2008, Kpodékon et al., 2009). The average daily gain is ranged from $18 \mathrm{~g}$ to $28 \mathrm{~g} / \mathrm{d}$ (Kpodekon et al., 2009b). The average live weight of rabbits after fattening during a period of 56 days is ranged from $1.9 \mathrm{~kg}$ to 2 kg (Djago and Kpodékon 2007; Kpodékon et al., 2009a,b). These performances are considerably lower than those obtained in the European countries. This difference is not only related to the genotype of rabbit and the rearing conditions but also to the improvement of their reproductive performances by hormonal methods (Perrier et al., 2000; Theau-Clement, 2008).

The relatively high cost of conventional oestrus synchronization products, the delicacy of their instructions and packaging requirements do not allow all farmers to use it wisely.

Therefore, the valuation of local hormonal plant resources becomes necessary. The study carried out by Koutinhouin et al. (2014) on the impact of Synedrella nodiflora (L.) Gaertn leaves used in rabbit feeding as feed supplement on the reproductive performance showed that such leaves improves fertility rate and litter size, and reduces significantly the mortality rate from birth to weaning. As found for Synedrella nodiflora (L.) Gaertn, Cissus populnea (Guill \& Perr) can be used in the improvement of reproductive performances of breeding animal because of its follicle-stimulating effect. According to Yakubu et al. (2014), the aqueous extract of $C$. populnea stem could be employed for the enhancement of normal functioning of the ovary and uterus as it promotes the synthesis of estrogen, progesterone, FSH and LH in the female rats. The findings of Ojekale et al. (2015) suggest that oral administration of Cissus populnea aqueous extract improves spermatogenesis in male wistar rats.

Then, it will be very useful to quantify the efficiency of Cissus populnea (Guill \& Perr) and Synedrella nodiflora (L.) Gaertn leaves used as feedstuff on the reproductive parameters in rabbit does in order to better valuate those sex hormone plant in rabbit breeding in Benin.

Synedrella nodiflora (L.) Gaertn is described in the literature as having several medicinal properties (Hidayat, 2001a; Bhogaonkar et al., 2011; Wijaya et al., 2011; Amoateng et al., 2012). Its leaves are reported as containing estradiol, haageanolide and alkane, sterol and triterpenes (Hidayat, 2001b). Moreover, this plant species is particularly rich in sesquiterpene lactones, polyacetylenes, steroids, terpenoids, alkaloids, saponins and various heterocyclic compounds (Bhogaonkar et al., 2011).

Belonging to the family of Vitaceae, Cissus populnea (Guill. and Perr.) commonly known as food gum is a strong woody vine, $8-10 \mathrm{~m}$ long, $7.5 \mathrm{~cm}$ in diameter and widely distributed across the tropics in West Africa (Burkill, 2000). Cissus populnea has been reported in several studies to be used in the management of infertility in males, skin diseases, sickle cell, antimicrobial, anti-helminthic, diuretics (Moody et al., 2003; Ojekale et al., 2006).

Phytochemical profile of Cissus populnea leaves indicating that its very rich in saponins $(2.85 \pm 0.35 \mathrm{mg} / \mathrm{g})$, anthraquinones $(2.00 \pm 0.14 \mathrm{mg} / \mathrm{g})$ and flavonoids $(0.39 \pm 0.03 \mathrm{mg} / \mathrm{g})$ (Soladoye and Chukwuma, 2012). The stem bark has been reported to contain carbohydrates, tannins, cyanogenic glycosides, anthraquinones, saponins, cardiac glycosides and flavonoids (Ibrahim et al., 1993).

Although some authors report that the aqueous extracts of the leaves of Cissus populnea (Guill. and Perr.) and Synedrella nodiflora (L.) Gaertn are toxic (Olukunle and Abatan, 2008; Dutta et al., 2012; Soladoye and Chukwuma, 2012), it is interesting to assess the effect of their leaves used by oral route through animal feeding 
since these plants are available freely as weeds in Benin and consume ad libitum by rabbit, sheep and goat kept under traditional rearing system.

The aim of the present work was to compare the impact of incorporation of Cissus populnea (Guill. and Perr.) and Synedrella nodiflora (L.) Gaertn leaves in the diet on reproductive performances of rabbits does of common breed reared in Benin.

\section{Material and Methods:- \\ Area of study:-}

The study was conducted from March, 2015 to December, 2016 in three rabbit farms in the municipality of Abomey-Calavi in Benin (figure1). Situated at latitude of $6^{\circ} 27^{\prime}$ north and at a longitude of $2^{\circ} 21^{\prime}$ east, the Municipality of Abomey-Calavi covers an area of $650 \mathrm{~km} 2$ with a population of 307745 inhabitants (INSAE 2010). This area exhibits climatic conditions of sub-equatorial type, characterized by two rainy seasons with an uneven distribution of rainfall: major (from April to July) and minor (from September to November). These two seasons are separated by a dry season. Average rainfall is close to $1200 \mathrm{~mm}$ per year. The monthly average temperatures vary between 27 and $31{ }^{\circ} \mathrm{C}$ and the relative air humidity fluctuates between $65 \%$, from January to March, and 97\%, from June to July.

\section{Vegetal material:-}

The vegetal materials used herein were Cissus populnea (Guill. and Perr.) and Synedrella nodiflora (L.) Gaertn. As reported by Koutinhouin et al. (2014), the genus Synedrella is a monotypic genus, belonging to the tribe Heliantheae, and taxonomically close to Wedelia. Synedrella nodiflora (L.) Gaertn is a highly variable, weedy species. Synedrella nodiflora (L.) Gaertn is of Asteraceae family, annual plant and an erect branched ephemeral herb usually $30-80 \mathrm{~cm}$ tall (Hidayat, 2001a). This plant is originated from America and now distributed pan-tropically and occurring throughout the West African Region.

Belonging to the family of Vitaceae, Cissus populnea (Guill. and Perr.) commonly known as food gum is a strong woody vine, $8-10 \mathrm{~m}$ long, $7.5 \mathrm{~cm}$ in diameter and widely distributed across the tropics in West Africa (Burkill, 2000).

\section{Animal management:-}

The current study was carried out on 120 nulliparous rabbits does and 24 males divided into 3 lots of 48 including 40 nulliparous females and 8 males. Each rabbit does was housed in individual flat-deck wire-mess cages and fed with a balanced pellet diet ad libitum (2677 DE/kg, 18.8\% crude protein). Water was also supplied ad libitum. Lighting program was constant, 16 hours-light: 8 hours-dark, and ventilation was natural.

In lot 1, the animals hadn't received any plant treatement based on Cissus populnea (Guill. and Perr.) and Synedrella nodiflora (L.) Gaertn leaves and were fed with a conventional pellet feeds. In lot 2, rabbits do and males were subjected to a conventional pellet feeds containing $10 \%$ of dry leaves flour of Cissus populnea (Guill. and Perr.).

In lot 3, rabbits do were subjected to a conventional pellet feeds containing $10 \%$ of dry leaves flour of Synedrella nodiflora (L.) Gaertn.

Males were allowed to mate twice with the same doe at the $11^{\text {th }}$ day post-parturition. Receptivity was assessed visually during mating. The pregnancy was determined by palpation. After kidding, does and their bunnies were housed together up to weaning.

Health monitoring was based on the use of aseptic foot baths at the entrance of each farm buildings; vitamin and antibiotics drenching was used to prevent disease. Preventive treatment against coccidiosis was also done. A standard prophylactic endoparasitic and ectoparasitic control schedule was applied. Occasional diseases were treated specifically according to the clinical signs detected.

\section{Data collection:-}

Data collection was done from the individual data record form of each reproductive animal and young rabbit by lot. In total, the study of reproductive parameters was recorded on 120 rabbit does and the weight growth was evaluated from their young rabbits. The number of females in estrus, the number of mated females and the number of pregnant 
females found after palpation, the number of kidding females, the number of stillborn, the live weight of kids at birth and the live weight of kits at weaning $\left(35^{\text {th }}\right.$ day post-birth) were also recorded.

\section{Statistical analysis:-}

The variables included in the data analysis were: litter size at birth and at weaning, the fertility rate, kidding rate, the stillbirth rate, the mortality rate from birth to weaning and the live weight of kids at birth and at 35 days post-birth. These data were analyzed using the SAS (Statistical Analysis System, 2006) software. Proc GLM procedure was used for variance analysis. The test of Fisher was used to evaluate the effect of the treatment on the different growth and reproductive traits considered. Means comparisons were made by Student t-test.

\section{Results And Discussion:-}

Effect of Cissus populnea (Guill. and Perr.) and Synedrella nodiflora (L.) Gaertn leaves on the litter size and growth

The effect of Synedrella nodiflora (L.) Gaertn leaves was significant $(\mathrm{P}<0.001)$ on litter size at birth and at weaning; the live weight of young rabbits at birth, at 35 days and at 56 days post-birth (Table 1). Indeed, the highest number of born alive were recorded in the lot 3 ( 7.3 young rabbits) and lot 2 ( 7.03 young rabbits), while the lowest values $(\mathrm{P}<0.001)$ were recorded in the control group (5.52 young rabbits). Therefore, Cissus populnea (Guill. and Perr.) and Synedrella nodiflora (L.) Gaertn leaves improve significantly the litter size in rabbit does, and then can improve profitability of rabbit breeding in sub-Saharan Africa. According to Apori et al., (2014), litter size in rabbits is regarded as one of the most important economic traits in any breed development and improvement programs for intensive meat production. According to Moce and Santacreu (2010) most maternal lines are selected based on litter size at weaning, since this trait reflects both the prolificacy and mothering ability of the doe.

In the current study, the live weights at birth, at 35 days and at 56 days old of young rabbits from the control group were higher $(\mathrm{P}<0.05)$ than those recorded in the experimental groups (lots 2 and 3$)$. The average daily gain (ADG) recorded in animals of lot 3 (32.2 g/day) fed with pellet diet containing Synedrella nodiflora (L.) Gaertn leaves was the highest followed by the animals of the control lot $(27.07 \mathrm{~g} / \mathrm{day})$. The average daily gain (ADG) recorded in animals of lot 2 suggested to pellet diet containing Cissus populnea (Guill. and Perr.) leaves was intermediary.

This impact of Synedrella nodiflora (L.) Gaertn leaves used as feed supplement for rabbits on the litter size and young rabbit growth could be related to the chemical composition of the leaves of $S$. nodiflora (L.) Gaertn, and more specifically to its hormonal content. According to Hidayat (2001b), S. nodiflora (L.) Gaertn contains estradiol and haageanolide. Furthermore, leaf contains alkane, sterol and triterpenes. The study of Hidayat (2001b) on the properties of S. nodiflora (L.) Gaertn reveals also that upon steam distillation of the leaves, Synedrella nodiflora (L.) Gaertn yields a yellow colored essential oil $(0.02 \%)$, with the terpenes 'beta'-caryophyllene, 'beta'-farnesene, germacrene-D and 'beta'-cubebene as major components. From the ethanol extract of the whole plant, the triterpenoid saponin nodifloside A (oleanolic acid 3-O-'beta'-D-xylopyranosyl-'beta'-D-glucopyranuronosyl methylate) was isolated, together with the triterpenoid oleanic acid-3-O-'beta'-D-glucopyranuronosyl methylate, and the steroids 'beta'-sitosterol, stigmasterol, stigmasterol-3-O-'beta'-D-glycoside and rosasterol. Synedrella nodiflora (L.) Gaertn also contains a high content of estradiol. Moreover, since 1978, Mannan and Ahmad (1978) have cited Synedrella nodiflora (L.) Gaertn in the 4 main sex hormones plants (Synedrella Nodiflora (L.) Gaertn, Heliotropicum indicum, Belva chal and Phyllanthus neruri) of Bangladeshi after his preliminary study on sex hormones of medical importance in Bangladeshi plants.

The average total born per litter in the experimental lots are slightly higher than those reported by Kpodekon et al. (2004), Akpo et al. (2008), Koutinhouin et al. (2009b). These authors had recorded total born ranging from 5.7 to 6.6, and total weaned young rabbit ranged from 4.8 to 5.7 per birth in Common rabbits reared in Benin. However, those performances found herein are comparable to those reported by Mahmoud (2008) which recorded an average of 8 young rabbits for litter size at birth and 6 young rabbit for litter size at weaning in rabbit of Néo-Zelandais Blanc, Californien and Géant Blanc breeds reared in a healthier farming system in Canada. This slight difference could be due not only to the genotype, but can also be linked to the best breeding conditions and climate factors that significantly affect the ability and frequency of females ovulate as was reported Hulot et al. (1981) and (Ouyed, 2006). The variation found in the live weight of the young rabbit at birth, at 35 days old and at 56 days old according the lot in the current study could be due to the difference in the litter size with the low litter size results in high live weight at birth, at 35 days old and at 56 days old. This finding is consistent with the reports of Ouyed et al. (2007) who indicate a negative relationship between litter size and growth performance in rabbit. The live weight increases 
when the litter size decreases. The gradual increase in body weight of young rabbits with age found herein is consistent with the results of Ouyed et al. (2010) in rabbit in rabbit of Neo-Zelandais Blanc, Californien and Geant Blanc breeds reared in a healthier farming system in Canada.

Effect of Cissus populnea (Guill. and Perr.) and Synedrella nodiflora (L.) Gaertn leaves on the fertility rate, birth rate, stillbirth rate and birth-weaning mortality rate

Fertility rates, birth rate, stillbirth rate and birth-weaning mortality rate varied significantly according to the lot $(\mathrm{P}<0.001$; table 2$)$. The fertility rate of animals of lot 2 and lot 3 , where rabbit does were fed respectively with pellet diet containing Synedrella nodiflora (L.) Gaertn leaves and pellet diet containing Cissus populnea (Guill. and Perr.) leaves was respectively of $90 \%$ and $92.5 \%$, to $85 \%$ for the control lot $(\mathrm{P}<0.001)$. The kidding rate of the experimental lots was $100 \%$ to $86 \%$ in the control lot $(\mathrm{P}<0.001)$. Similarly, the highest stillborn rate $(6.35 \%)$ was recorded in control lot while the lowest stillbirth rate $(2.9-4.1 \%)$ were obtained in animals of experimental lots $(\mathrm{P}<0.001)$. The highest mortality rate recorded from the birth to the weaning $(8.08 \%)$ was observed in animals of Lot $1(\mathrm{P}<0.001)$. This variation of the fertility rate found herein could be related to the sex hormones content of the plant notably the estradiol content (Mannan and Ahmad, 1978; Hidayat, 2001b). According to Mukasa-Mugerwa (1989), prepubertal ovaries also respond when transplanted to mature animals and injecting oestradiol results in LH release in calves as young as 3 months old. The possible causes of sexual maturation at puberty appear to be an increase in pituitary hormones output culminating in increased size and activity of the ovaries and maturation of the hypothalamo-pituitary axis, resulting in secretion of gonadotrophins. Therefore, the highest fertility rate and litter size found in the current study in the rabbit suggested to Synedrella nodiflora (L.) Gaertn leaves used as feed supplement in the diet may be related to the hormonal profile of the plant.

Ouyed (2006) found fertility rates of palpation of $92.1 \%$ and $93.6 \%$ respectively in white New Zealand and Californian rabbits reared in a healthier farming system in Canada. The average stillborn recorded in the current study are significantly lower than those reported for the same rabbit breed in the literature in Benin (Akpo, 2004; Kpodékon et al., 2004; Lebas, 2004; Akpo et al., 2008; Koutinhouin et al., 2009a) in White rabbit of Algeria (Zerrouki et al., 2007).

This difference may be related to the kidding rank because fertility rate at palpation increase with the kidding rank of rabbit does (Ouyed et al., 2007). In the current study, we have used primiparous females whose maternal instinct might be more developed compared to nulliparous does used by Akpo (2004); Kpodékon et al. (2004); Lebas (2004); Akpo et al. (2008); and Koutinhouin et al. (2009b). This mortality rate from birth to weaning obtained herein is comparable to that recorded by Fellous et al. (2012) in rabbits of the Algerian high experimental station population, but remains lower than $21.5 \%$ and $36.61 \%$ respectively recorded by Akpo (2004) in the same rabbit breed reared in the same agro-ecological area of Benin. Number range may cause discrepancies between the different results. Mortality rates birth-weaning recorded in the four experimental groups in this study are lower than the standard (10-15\%) indicated by Lebas (2004). Bolet et al. (2004) had reported mortality rate from birth to weaning ranging from 9.5 to $38.5 \%$ in rabbits of Argenté de Champagne, INRA 9077, Thuringer, Vienna White, Fauve de Bourgogne, Belgian Hare, Chinchilla, English and Himalayan breeds fed with a commercial diet ad libitum in France.

\section{Effect of Cissus populnea (Guill. and Perr.) and Synedrella nodiflora (L.) Gaertn leaves on hematological parameters}

The variation of hematological parameters is given in table 3. White blood cell concentrations in red blood cell, hemoglobin, and hematocrit are respectively $6.23 \times 10^{3} / \mu \mathrm{L}, 5.63 \times 10^{6} / \mu \mathrm{L}, 11.3 \mathrm{~g} / \mathrm{Dl}$ and $37.50 \%$ in rabbits in the control group, against $6.05 \times 10^{3} / \mu \mathrm{L}, 5.63 \times 10^{6} / \mu \mathrm{L}, 11,55 \mathrm{~g} / \mathrm{Dl}$ and $38.85 \%$ in rabbits of lot 2 and $6.96 \times 10^{3} / \mu \mathrm{L}$, $5.79 \times 10^{6} / \mu \mathrm{L}, 11.2 \mathrm{~g} / \mathrm{Dl}$ and $37.3 \%$ in rabbits of the lot 3 .

On the whole, blood count analysis show no particular hematological problem. These remarks are comparable with the work results of Sakande et al. (2003) on study of biologic tolerance of antiplasmodial plante Momordica charantia (Cucurbitaceae) in albinos rabbits.

The leaves of Cissus populnea (Guill. and Perr.) and S. nodiflora provoked no changes in erythrocytes and leukocytes cell strains. This result is similar with that of Maduka et al. (2003). Furtheremore, the results of the study of influence of Sacoglottis gabonensis on secondary effects of 2.4- dinitrophénylhydrazin in bood and cell 
metabolism showed that the use of Sacoglottis gabonensis for rats don't modify the level of red blood cells, hemoglobin, hematocrit, white blood cells, lymphocytes, neutrophils and monocytes.

However, the effect of dietary supplementation using node weed (Synedrella nodiflora) on the toxicity induced by single or combined doses of copper and lead in the guinea pig (Cavia porcellus) was investigated by Tawari-Fufeyin and Omonigho (2007). It comes out from their study that elevated lymphocyte levels were observed in animals with node weed supplemented diet. According to these authors, histological changes were pronounced as evidenced by massive lymphocyte infiltration of the liver and kidney which was more severe in animals with node weed supplemented diet.

\section{Conclusion:-}

Overall, the main effect of leaves of Cissus populnea (Guill \& Perr) and Synedrella nodiflora (L.) Gaertn is to increase litter size and to reduce kidding interval in rabbit does. Synedrella nodiflora (L.) Gaertn leaves can therefore be used as Pregnant Mare Serum Gonadotrophin supplier in family rabbit breeding to improve reproductive parameters in rabbit does. Since Cissus populnea and Synedrella nodiflora are an available plant known as advent or weed in Benin, the current results will be useful for local rabbit breeders in the improvement of the profitability of rabbit breeding in sub-saharan Africa. The active ingredient and mechanism of action of leaves of Cissus populnea and Synedrella nodiflora on the reproductive performances could be a subject for further studies.

\section{Acknowledgement:-}

The authors are very much grateful to the lab of Animal Husbandry and Quality Control of Animal Products of the University of Abomey-Calavi. They also thank rabbit breeders of Abomey-Calavi (Benin) for giving all types of support in conducting this study.

\section{Competing interests:-}

The authors declare that they have no conflict of interest.

Table 1:- Effect of of Cissus populnea (Guill \& Perr) and Synedrella nodiflora (L.) Gaertn on the average litter size at birth and at weaning and ADG

\begin{tabular}{|l|l|l|l|l|l|l|l|}
\hline \multirow{2}{*}{ Variables } & \multicolumn{2}{l|}{ Lot 1 (Control lot) } & \multicolumn{2}{l|}{ Lot 2 (C. populnea) } & \multicolumn{2}{l|}{ Lot 3 (S. nodiflora) } & \multirow{2}{*}{ ANOVA } \\
\cline { 2 - 7 } & Mean & SE & Mean & SE & Mean & SE & \\
\hline Born alive & $5.52 \mathrm{a}$ & 0.13 & $7.03 \mathrm{~b}$ & 0.17 & $7,3 \mathrm{~b}$ & 0.14 & $* * *$ \\
\hline Total born & $5.78 \mathrm{a}$ & 0.13 & $7.1 \mathrm{~b}$ & 0.17 & $7.47 \mathrm{~b}$ & 0.13 & $* * *$ \\
\hline Litter size at weaning & $4.87 \mathrm{a}$ & 0.11 & $6.37 \mathrm{~b}$ & 0.16 & $6.85 \mathrm{~b}$ & 0.17 & $* * *$ \\
\hline Kidding interval & $61.9 \mathrm{a}$ & 0.5 & $45.5 \mathrm{~b}$ & 0.27 & $46.1 \mathrm{~b}$ & 0.48 & $* * *$ \\
\hline W 35 $(\mathbf{g})$ & $726.8 \mathrm{a}$ & 10.1 & $648.8 \mathrm{~b}$ & 7.4 & $608.75 \mathrm{c}$ & 9.81 & $* * *$ \\
\hline W 56 $(\mathbf{g})$ & $1306.8 \mathrm{a}$ & 10.1 & $1188.8 \mathrm{~b}$ & 7,39 & $1276.3 \mathrm{c}$ & 11.2 & $* * *$ \\
\hline ADG 35-56 & $27.07 \mathrm{a}$ & 0.27 & $25.86 \mathrm{~b}$ & 0.4 & $32.18 \mathrm{c}$ & 0.12 & $* * *$ \\
\hline
\end{tabular}

SE: Standard Error, ANOVA: Analysis of Variance, ***: P<0.001. The means between the classes of the same line followed by different letters differ significantly with the threshold of $5 \%$.

Table 2:- Effect of Gonaser and Synedrella nodiflora (L.) Gaertn on the fertility rate, birth rate, stillbirth rate and birth-weaning mortality rate

\begin{tabular}{|c|c|c|c|c|c|c|c|}
\hline \multirow[t]{2}{*}{ Variables } & \multicolumn{2}{|c|}{$\begin{array}{l}\text { Lot } 1 \\
\text { (Control lot) }\end{array}$} & \multicolumn{2}{|c|}{$\begin{array}{l}\text { Lot } 2 \\
\text { (C. populnea) }\end{array}$} & \multicolumn{2}{|c|}{$\begin{array}{l}\text { Lot } 3 \\
\text { (S. nodiflora) }\end{array}$} & \multirow[t]{2}{*}{ ANOVA } \\
\hline & Mean & SE & Mean & SE & Mean & SE & \\
\hline Fertility rate (\%) & $85 \mathrm{c}$ & 1.44 & $90 \mathrm{~b}$ & 1.47 & $92.5 \mathrm{a}$ & 1.44 & $*$ \\
\hline Kidding rate $(\%)$ & $86 \mathrm{~b}$ & 0.41 & $100 \mathrm{a}$ & 0 & $100 \mathrm{a}$ & 0 & $* * *$ \\
\hline Stillbirth rate (\%) & $6.35 \mathrm{a}$ & 0.05 & $2.91 \mathrm{~b}$ & 0.41 & $4.16 \mathrm{c}$ & 0.4 & $* * *$ \\
\hline Birth-weaning mortality rate $(\%)$ & $8.08 \mathrm{a}$ & 0.4 & $6.41 \mathrm{a}$ & 0.4 & $6.83 \mathrm{a}$ & 0.4 & NS \\
\hline
\end{tabular}

SE: Standard Error, NS: P> 0.05; ANOVA: Analysis of Variance, *: $P<0.05$; ***: $P<0.001$. The means between the classes of the same line followed by different letters differ significantly with the threshold of $5 \%$. 
Table 3:- Effect of Gonaser and Synedrella nodiflora (L.) Gaerth on the hematological parameters in rabbit do

\begin{tabular}{|l|l|l|l|l|l|l|l|}
\hline \multirow{2}{*}{ Variables } & \multicolumn{2}{l}{$\begin{array}{l}\text { Lot } 1 \\
\text { (Control lot })\end{array}$} & \multicolumn{2}{l|l}{$\begin{array}{l}\text { Lot } 2 \\
\text { (C. populnea })\end{array}$} & \multicolumn{2}{l}{$\begin{array}{l}\text { Lot 3 } \\
\text { (S. nodiflora) }\end{array}$} & \multirow{2}{*}{ ANOVA } \\
\cline { 2 - 8 } & Mean & SE & Mean & SE & Mean & SE & \\
\hline White Blood Cell $\left(10^{3} / \mathrm{uL}\right)$ & 6.23 & 0.48 & 6.05 & 0.10 & 6.96 & 0.038 & NS \\
\hline Red Blood Cell $\left(10^{6} / \mathrm{uL}\right)$ & 5.63 & 0.08 & 5.63 & 0.08 & 5.79 & 0.029 & NS \\
\hline Hemoglobin $(\mathrm{g} / \mathrm{dL})$ & 11.30 & 0.35 & 11.55 & 0.20 & 11.20 & 0.058 & NS \\
\hline Hematocrit $(\%)$ & 37.50 & 0.98 & 38.85 & 0.84 & 37.30 & 0.346 & NS \\
\hline
\end{tabular}

SE: Standard Error, NS: P> 0.05; ANOVA: Analysis of Variance.

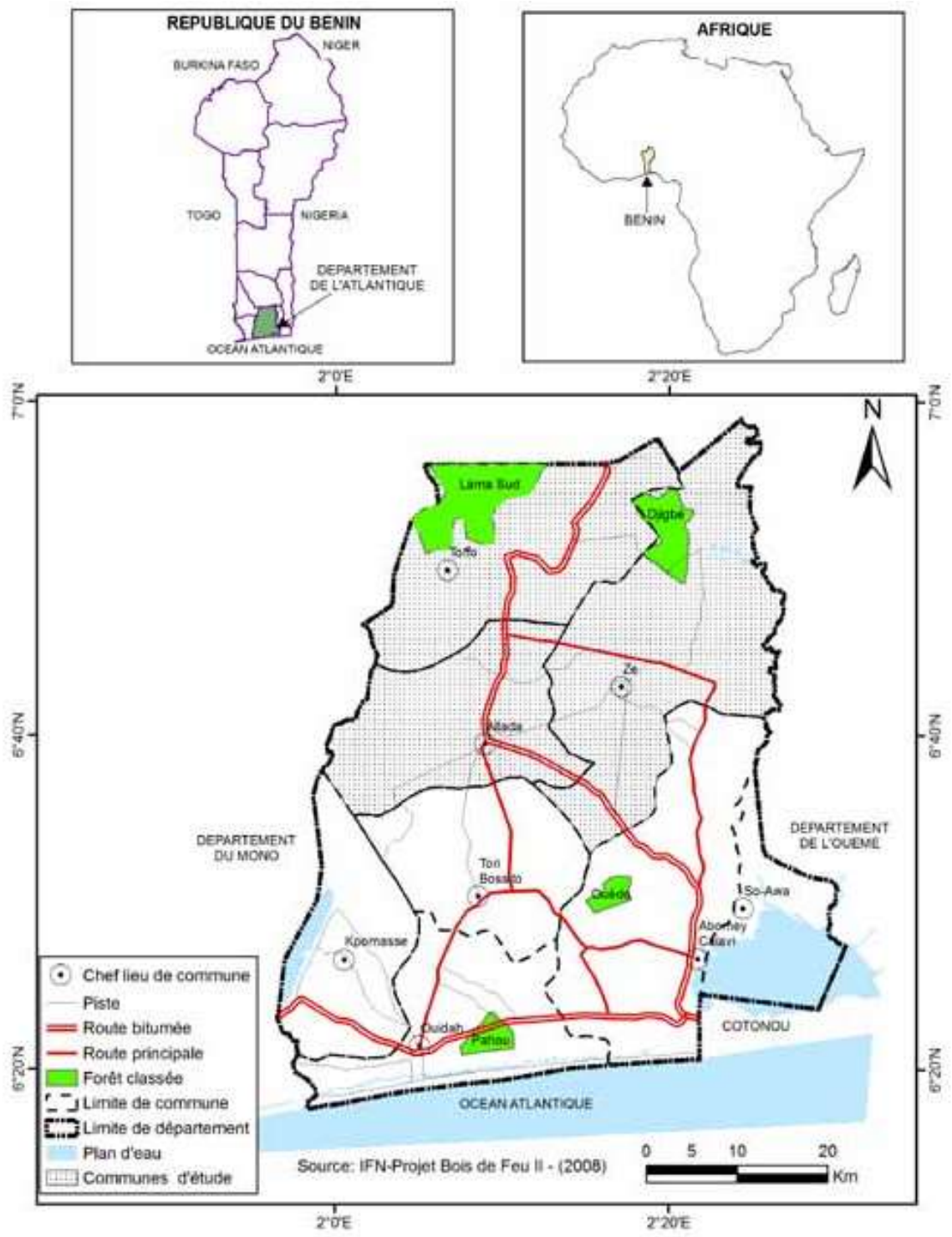

Figure 1:- Study area (Abomey-Calavi, Benin)

\section{References:-}

1. $\mathrm{ABeC},(2004)$ : L'Association Béninoise de la Cuniculture (ABeC). Rapport d'activité, $102 \mathrm{p}$.

2. $\mathrm{ABeC},(2007)$ : Répertoire actualisé des éleveurs de lapin. Cotonou, ABeC. 26 p.

3. Aglossi, E. (2004): Etude de quelques paramètres zootechniques de trente(30) élevages cunicoles de l'Association Béninoise des cuniculteurs $(\mathrm{ABeC})$. Rapport de stage de fin de formation pour l'obtention du Diplôme Universitaire de technologie(DUT), 75p. 
4. Akpo, B. (2004): Etudes comparative de quelques performances zootechniques de 20 femelles de lapin au CE.CU.R.I. Mémoire de fin d'études pour l'obtention du Diplôme d'ingénieur des travaux(DIT), 85p.

5. Akpo, Y., Kpodékon, T.M., Tanimomo, E., Djago, A.Y., Youssao, A.K.I. and Coudert, P. (2008): Evaluation of the reproductive performance of a local population of rabbits in south Bénin. $9^{\text {th }}$ World Rabbit Congress - June 10-13, Verona - Italy; $12 \mathrm{p}$.

6. ASFC, (2008) : Répertoire actualisé des races de lapins. Association Scientifique Française de Cuniculture. Cuniculture Magazine, Vol, (33), 56-66.

7. Bhogaonkar, P.Y., Dagawal, M.J. and Ghorpade, D.S. (2011): Pharmacognostic studies and antimicrobial activity of Synedrella nodiflora (L.) Gaertn (1.) Gaertn. Bioscience Discovery, 2 (3):317-321.

8. Bourdillon, A., Chmitelin, F., Jarrin, D., Parez, V. and Rouillere, H. (1992): Effects of a PMSG treatment on breeding results of artificially inseminated rabbits. J. Appl. Rabbit Res. 15, 530-537.

9. Burkill, H.M. (2000): The Useful Plants of West Tropical Africa, Vol. 5. Royal Botanic Gardens, Kew, pp. 296 - 297.

10. Castellini, C. (1996): Recent advances in rabbit artificial insemination. Proceedings of the $6^{\text {th }}$ World Rabbit Congress, Toulouse, Vol. 2, 13-26.

11. Djago, A. and Kpodékon, M. (2000): Le guide pratique de l'éleveur de lapins en Afrique de l'ouest. P. 9-60, 81.

12. Dutta, M., Nath, A.K., Uddin, M.Z., Hossain, M.A., Morshed, M.M. and Kawsar, M.A. (2012): In vitro antioxidant total phenolic content and brine shrimp lethality studies in Synedrella nodiflora. Inter J Pharma Sci Res.; 3(5): 1528-31.

13. Ennafaa, H., Monnerot, M., El Gaaied, A. and Mounolou, J. (1987): Rabbit mitochondrial DNA: preliminary comparison between some domestic and wild animals, G.S.E., 19, 3, 297-288.

14. Fagbohoun, A. (2006) : Etude de l'effet de l'incorporation du tourteau de tournesol dans l'alimentation sur les performances zootechniques du lapin au Bénin. Thèse Doct. Vét., Eismv, Dakar, 68p.

15. FAO, (2004): Banque de données, FAOTSTAT: Agriculture. Consulté le 27 février 2004 à l'adresse http//apps.fao.org/page/collection ?suset=agriculture=fr

16. FAO (2008). FAOSTAT : Agriculture. http://apps.fao.org/page/collections.

17. Fielding, D. (1993) : Le lapin. -Paris : Edition Maisonneuve et Larose ; l'A.C.C.T. C.T.A. -142p.

18. Goudjo, A. (2010) : Evaluation des performances de reproduction des lapines en sélection et des femelles croisées avec des mâles de souche INRA 1777 au CECURI (Centre Cunicole de Recherche et d'Information) Benin. Mémoire de Master professionnel, Université d'Abomey-Calavi, 63p.

19. Henaff, R. and Jouve, D. (1988) : Mémento de l'éleveur de lapin. Edition Association Française de cuniculture. Lempdes, $448 \mathrm{p}$.

20. Houindo, E. (2002) : Effets du rang de mise-bas sur la fertilité des lapines au Sud et au Centre du Bénin, Mémoire de fin d'étude pour l'obtention du Diplôme d'Ingénieur des Travaux, Université d'Abomey-Calavi, Bénin : 66p.

21. Ibrahim, H., Rai, P.P. and Bangudu, A.B. (1993): Pharmacognostic studies of the Stem Bark of Cissus populnea Guill \& Perr. Glimpses in Plant Research 1: 175 - 180.

22. INRA, (2004) : Valeur nutritionnelle de la viande de lapin. Prod. Anim, 17 (5), 373-383

23. INRA, (2010) : Le lapin, entre élevage et amélioration; Agriculture - Janvier 2010.

24. Jussiau, R., Montmeas, L. and Papet, A. (2010): Amélioration génétique des animaux d'élevage, bases scientifiques, sélection et croisements, educagri ed, $322 \mathrm{p}$.

25. Kenoukon, C. (2005) : Répertoire actualisé des éleveurs-Cotonou : A. Be. C., 26p.

26. Koutinhouin, G.B., Youssao, A.K.I., Dougnon, T.J., Kpodékon, T.M., Djago, Y., Aglossi, E. and Djivo L (2009a). Influence du rang de mise bas sur les paramètres de reproduction des lapins au Sud du Bénin. Revue Africaine de Santé et de Productions Animales, Vol.7 $\mathrm{N}^{\mathrm{O}}$ 1, E.I.S.M.V. de Dakar, 85p.

27. Koutinhouin, G.B., Youssao, A.K.I., Kpodékon, T.M., Djago, Y. and Houenon, R., (2009b) : Incidence de la séparation mère-portée sur la fertilité des lapines allaitantes et la taille de la portée au Sud du Bénin.Bulletin de la Recherche Agronomique du Bénin; 15p.

28. Kpodékon, M. (1988) : Le point sur l'élevage de lapin en république du Bénin : Perspectives d'avenir. CuniSciences., $4: 15-26$.

29. Kpodékon, M. and Coudert, P. (1993) : Impact d'un Centre Cunicole de Recherche et d'Information sur la recherche et le développement de la cuniculture au Bénin. World Rabbit Sci., 1, 25-30.

30. Kpodékon, M. and Coudert, P. (2002) : Analyse de la Gestion Technico-économique des élevages cunicoles de l'Association Béninoise des Cuniculteurs, 11p.

31. Kpodékon, T.M. (1988) : Le point sur l'élevage du lapin en République du Bénin. Perspectives d'avenir. CuniScience, 4 (2), 15-26. 
32. Kpodékon, T.M. and Coudert, P. (1993) : Impact d'un centre cunicole de recherche et d'information sur la recherche et le développement de la cuniculture au Bénin. World Rabbit Science (1993), I (1), 25-30.

33. Kpodékon, T.M., Djago, Y., Farougou, S., Coudert, P. and Lebas, F. (2004): Results of the technical management of four rabbit farms in Benin. Proceedings of the 8th World Rabbit Congress, Puebla (Mexico) Sept. 2004, WRSA ed., 1134-1140.

34. Kpodékon, T.M., Youssao, A.K.I., Koutinhouin, B., Djago, Y., Houezo, M. and Coudert, P. (2006): Influence des facteurs non génétiques sur la mortalité des lapereaux au Sud du Bénin. Ann. Med. Vet., 150 (2), $197-201$.

35. Kpodékon, T.M., Youssao A.K.I., Koutinhouin, B.G., Missohou, A., Fayomi, J., Fagbohou, A. and Djago, Y. (2010) : Comparaison des performances de croissance de lapereaux en engraissement nourris par un aliment à base de tourteau de tournesol, soit sous forme farineuse soit sous forme granulée. Livestock Research for Rural Development, 22 (01).

36. Kpodékon, T.M., Youssao, A.K.I., Koutinhouin, G.B., Fayomi, J., Fagbohou, A. and Djago, Y. (2009b): Comparaison des performances de croissance de lapereaux en engraissement nourris par un aliment à base de tourteau de tournesol, soit sous forme farineuse soit sous forme granulée. Livestock Research for Rural Development 21 (12).

37. Kpodékon, T.M., Youssao, A.K.I., Koutinhouin, G.B., Missohou, A., Fayomi, J., Fagbohou, A. and Djago, Y. (2009a): Substitution du tourteau de palmiste par le tourteau de tournesol dans l'alimentation des lapins à l'engraissement. Livestock Research for Rural Development, Volume 21, 12p.

38. Lebas, F. (2000) : Les races de lapins. Spécificités zoologiques, Standards officiels. Fédération Française de Cuniculiculture, Paris France, 18p.

39. Lebas, F. (2004) : L'élevage du lapin en zone tropicale. Cuniculture MagazineVolume 31, page 3.

40. Maduka, H.C., Okoye, Z.S. and Eje, A. (2003) : The influence of Sacoglottis gabonensis stem bark extract and its isolate bergenin, Nigerian alcoholic beverage additives, on the metabolic and haematological side effects of 2,4-dinitrophenyl hydrazine induced tissue damage. Vas. Pharm., 39 : 317-324.

41. MAEP, (2012) : Rapport annuel d'activités, Ministère de l'Agriculture, de l'Elevage et de la Pêche, Cotonou, $150 \mathrm{p}$.

42. Maertens, L., Luzi, F. and Grilli, G. (1995) : Effects of PMSG induced oestrus on the performance of rabbit does : a review. World Rabbit Science 1995, 3(4), 191-199.

43. Mahmoud, G. (2008): A Study of some Productive and Reproductive traits in two Strains of Rabbits and their Crosses.Doctor of Philosophy. In Agricultural sciencesDepartment Of Animal Production Faculty Of Agriculture Al-Azhar University, 260p.

44. Mcnitt, J.I. (1992): Endocrinological approaches for commercial rabbit production. J. Appl.

45. Moody, J.O., Ojo, O.O., Omotade, O.O., Adeyemo, A.A., Olumese, P.E., Ogundipe, O.O. (2003): Anti-sickling potential of a Nigerian herbal formula (ajawaron HF) and the major plant component (Cissus populnea L. CPK). Phytother. Res. 17(10): 1173 - 1176.

46. Nteme, E.G.S. (2000) : Contribution à l'étude de la filière du lapin de chair (oryctolagus cuniculus) au Sénégal. Thèse Doct. Vét., Eismv, Dakar. Numéro 63 - Mars 2009 ; 253p.

47. Ojekale, A.B., Anthony, B., Oladipupo, A.L., Peter, I.J., Jamiu, A.O., Latifat, O.A. (2015) : "Cissus populnea (Guill \& Perr): A Study of the Aqueous Extract as Potential Spermatogenic Enhancers in Male Wistar Rats." American Journal of Medical and Biological Research 3, no. 5 124-127.

48. Ojekale, A.B., Lawal, O.A., Lasisi, A.K., Adeleke, T.I. (2006): Phytochemistry and spermatogenic potentials of extract of Cissus populnea (Guill and Per) stem bark. TSW Holistic Health Med. 1: 176 - 182.

49. Olukunle, J.O., Abatan, M.O. (2008) : The toxicological effects of aqueous extract of Synedrella nodiflora in rats. ASSET Series B; 7(1):81-9.

50. Quesney, G., Monnerot, M. (2004) : Apports de la biologie moléculaire à l'étude de la domestication : l'exemple du lapin. Ethnozootechnie, 75, 34-39.

51. Questel, G. (1984) : Contribution à l'étude de la fertilité chez le lapin domestique. Mémoire de fin d'études, INRA Paris-Grignon, France, 81p.

52. Rabbit Res. 15, 364-397.

53. Rougeot, J. (1981) : Origine et histoire du lapin, Ethnozootechnie, 27, 1-9.

54. Sakande, J., Nikiema, J.B., Lompo, M., Nacoulma, O.G., Bassene, E. and Guissou I.P. (2003): Study of the effect of an isolated anti-inflammatory principle of Borassusa ethiopum Mart's male inflorescences on the kinetics of C reactive protein (CRP). Le pharmacien d'Afrique, $166: 7-11$.

55. SAS, (2006) : SAS/STAT User's guide, vers, 6, 4th ed, Cary, NC,USA, SAS Inst.

56. Siagbo, O. (2004): Moyenne des saillies par mise-bas et productivité moyenne annuelle des lapines au CE.CU.R.I. Mémoire de fin d'études ; 75p. 
57. Soladoye, M.O., Chukwuma, E.C. (2012): Quantitative phytochemical profile of the leaves of Cissus populnea Guill. \& Perr. (Vitaceae) - an important medicinal plant in Central Nigeria. Arch. Appl. Sci. Res 4(1): 200 206.

58. Sorensen, M.K., Nordberg, E., Pedersen, J. and Christensen, L.G. (2008): Crossbreeding in dairy cattle: A Danish perspective. J. Dairy Sci., 91, 4116-4128.

59. Tawari-Fufeyin, P. and Omonigho, O. (2007): Effects of dietary supplementation of node weed (Synedrella nodiflora ) on toxicity of copper and lead in guinea pigs (Cavia porcellus). Toxicological \& Environmental Chemistry Vol. 89 , Iss. 2.

60. Theau-Clement, M. and Boiti, C. (1998): Biostimulation methods for breeding rabbit does: synthesis of the first results. World rabbit Science 1998, 6(1), 205-208.

61. Theau-Clement, M., Lebas, F., Pourjardieu, B. and Macier, P. (2008) : Effet des différentes doses de PMSG sur l'induction de la réceptivité sexuelle et la productivité des lapines conduites en insémination artificielle. 7ème journées de la recherche cunicole, Lyon 13-14 mai. P221-224.

62. Thoto, C. (2006) : Utilisation de la robénidine en qualité d'additif anticoccidien dans l'aliment : effet sur la croissance et le degré d'infestation des lapins à l'engraissement.Thèse Doct. Vét., Eismv, Dakar, 57 p.

63. Voïtan, A. (2003) : Indice de la méthode de séparation mère-portée sur la fertilité des lapines allaitantes et sur la croissance pondérale des lapereaux sous mère au CE.CU.R.I. ; Mémoire de fin d'études pour l'obtention du Diplôme d'Ingénieur des Travaux(DIT), 84 p.

64. Wabi, K. (2007) : Etude de la qualité commerciale et microbiologique des carcasses congelées de lapin de chair au Benin. Thèse de Docteur en Médecine Vétérinaire, Dakar, N¹0,109 p.

65. Yakubu, M.T., Salimon, S.S., Abdul-Rasheed, R.O., Opakunle, M.F., Jimoh, R.O., Nafiu, M.O. (2014) : Effects of Aqueous Extract of Cissus populnea Stem on Function Indices of the Ovary and Uterus of Female Wistar Rats. Centrepoint Journal (Science Edition) Volume 20, No. 2, pages $131-141$

66. Youssao, A.K.I., Koutinhouin, G.B., Kpodekon, T.M., Agnandjo, H., Toure, Z., Ahissou, A. and Renand, G. (2007): Variabilité génétique des performances de croissance et des mesures corporelles de jeunes bovins de race Borgou à la Ferme d'Elevage de l'Okpara. RASPA Vol.5 N03-4.

67. Zerrouki, N., Hannachi, R., Lebas, F. and Saoudi, A. (2007) : Productivité des lapines d'une souche blanche de la région de Tizi-Ouzou en Algérie. 12èmes Journées de la Recherche Cunicole, 27-28 novembre (2007) : Le Mans, France.141-144.

68. Zeuner, F. (1963): A history of domistificated animals, 19, the small Rodents: Rabbit, Hutchinson, London, 409-415. 